\title{
СТУПІНЬ ПРОЯВУ ТА РОЗПОВСЮДЖЕНІСТЬ СЕПТОРІОЗУ ЛИСТКІВ ПШЕНИЦІ ОЗИМОЇ ЗАЛЕЖНО ВІД СОРТУ
}

О. Г. Сухомуд, В. В. Любич

Уманський національний університет садівництва

Ступінь прояву та розповсюдженість септоріозу листя пшениці озимої залежать від погодних умов, фази вегетації культури та сорту. Найвищою інтенсивність ураження була у фазі виходу рослин у трубку, проте розповсюдженість захворювання - у фазах виходу в трубку, колосіння та молочної стиглості зерна.

\section{Септоріоз, сорт, інтенсивність ураження, розповсюдженість}

Серед збудників хвороб, які спричиняють плямистості листя пшениці, септоріоз займає основне місце за шкідливістю та поширенням. Захворювання небезпечне в усі фази вегетації культури і відноситься до хвороб, здатних викликати епіфітотії.

Шкідливість септоріозу виражається в пригніченні рослин, зменшенні асиміляційної поверхні, відставанні в рості, передчасному всиханні листків і всієї рослини та щуплості зерна. В Україні септоріоз пшениці поширений в усіх зонах вирощування зернових культур, особливо в Лісостепу. Найбільша шкідливість захворювання відмічається при пошкодженні трьох верхніх листків в період від початку колосіння до цвітіння, що призводить до повного всихання листків. До фази молочно-воскової стиглості недобір врожаю може сягати $40 \%$.

Локальний розвиток захворювання відмічається щорічно, частота епіфітотій - п'ять років 3 десяти. Чим раніше проявляється захворювання на рослинах, тим спустошливіші наслідки воно може мати. Одним з найбільш ефективних і екологічно безпечних способів захисту від хвороб є вирощування стійких і слабкосприйнятливих сортів пшениці. Проте у виробництві сорти, стійкі до септоріозу, відсутні [1-9]. Дані про динаміку інтенсивності та розвитку збудника септоріозу листя на сортах пшениці впродовж вегетації $€$ важливими як для розробки заходів захисту, так і для селекційної практики.

Мета і завдання досліджень. Метою роботи було виявлення сортів пшениці озимої, стійких до ураження септоріозом. Для цього необхідно встановити ступінь прояву та розповсюдженість септоріозу впродовж вегетації пшениці озимої залежно від сорту та погодних умов.

(C) О. Г. Сухомуд, В. В. Любич. 2013.

ISSN 0582-5075. Селекція і насінництво. 2013. Випуск 103. 
Методика та вихідний матеріал. Дослідження проводили впродовж 2011-2012 рр на дослідному полі кафедри захисту і карантину рослин Уманського НУС. Предметом досліджень були сорти пшениці озимої вітчизняної та зарубіжної селекції, включені до Державного реєстру сортів рослин, придатних для поширення в Україні у 2011 р. [10]. Об'єктом досліджень були збудники септоріозної плямистості листя (Septoria spp). Сорти висівали на ділянках площею $5 \mathrm{~m}^{2}$. Ступінь прояву, розповсюдженість хвороби, стійкість сортів до ураження септоріозом листя впродовж вегетації визначали за загальноприйнятими методиками [11-12]. Спостереження та обліки проводили у фазах весняного кущіння (двічі з інтервалом через 30 діб), виходу в трубку, колосіння і молочної стиглості зерна.

Погодні умови вегетаційного періоду 2011 р. були в цілому сприятливим для збудника септоріозу листя. Перші симптоми ураження було виявлено на початку третьої декади березня. У 2012 р симтоми захворювання було виявлено в фазу виходу рослин в трубку, тобто в другій декаді травня. Значні коливання середньодобових температур в подальшому не сприяли розвитку і поширенню септоріозу. Найвища інтенсивність та розповсюдженість захворювання рослин пшениці септоріозом за два роки досліджень були в фази колосіння та молочної стиглості зерна.

Результати і їх обговорення. У 2011 р. ступінь прояву хвороби під час першого обліку скадав $1,5-2,0 \%$, а розповсюдженість хвороби 30-45 \%. Суттєвої різниці між сортами ми не встановлено (табл. 1).

Таблиця 1

Ураження пшениці озимої септоріозом листя у фазу весняного кущіння залежно від сорту, 2011 р.

\begin{tabular}{|l|c|c|c|c|}
\hline \multirow{2}{*}{ Сорт } & \multicolumn{2}{|c|}{ Ступінь прояву хвороби (R) } & \multicolumn{2}{l|}{ Розповсюдженість хвороби (Р) } \\
\cline { 2 - 5 } & 1 -й облік & 2-й облік & 1-й облік & 2-й облік \\
\hline Явіс & 2,0 & 15,5 & 30,0 & 32,0 \\
\hline Емеріно & 1,7 & 12,5 & 35,0 & 40,0 \\
\hline Златоглава & 1,5 & 28,1 & 40,0 & 48,0 \\
\hline Скарбниця & 2,0 & 23,2 & 30,0 & 42,0 \\
\hline Ремеслівна & 2,0 & 29,5 & 45,0 & 45,0 \\
\hline Одеська 267 & 1,5 & 28,8 & 40,0 & 44,0 \\
\hline Атава & 2,0 & 25,4 & 30,0 & 36,0 \\
\hline Міхелуа & 1,5 & 26,4 & 40,0 & 44,0 \\
\hline Харус & 1,8 & 23,5 & 45,0 & 48,0 \\
\hline Юнона & 2,0 & 29,9 & 30,0 & 35,0 \\
\hline Трипільська & 1,7 & 26,4 & 30,0 & 32,0 \\
\hline Зорепад & 1,5 & 28,6 & 45,0 & 48,0 \\
\hline Господиня & 1,5 & 28,8 & 40,0 & 45,0 \\
\hline НІР & 0,1 & 1,1 & 1,7 & 1,9 \\
\hline
\end{tabular}


Через 30 діб ступінь прояву септоріозу був істотно вищим і коливався в межах 15,5-29,9 \% залежно від сорту, але кількість уражених рослин збільшувалась неістотно. У фазу весняного кущіння вища стійкість відносно септоріозу була у сортів Явіс та Емеріно. В 2012 р. у фазі кущіння ознак хвороби не виявлено.

У фазу виходу рослин в трубку ураженість листків пшениці озимої септоріозом за роки досліджень значно відрізнялась. Погодні умови для розвитку збудника септоріозу сприятливішими були у 2011 р (табл. 2).

Таблиця 2

Ураження пшениці озимої септоріозом листя у фазі виходу в трубку залежно від сорту, \%

\begin{tabular}{|l|c|c|c|c|}
\hline \multirow{2}{*}{ Сорт } & \multicolumn{2}{|c|}{$2011 \mathrm{p.}$} & \multicolumn{2}{c|}{$2012 \mathrm{p.}$} \\
\cline { 2 - 5 } & $\begin{array}{c}\text { Ступінь } \\
\text { прояву } \\
\text { хвороби } \\
(\mathrm{R})\end{array}$ & $\begin{array}{c}\text { Розповсюд- } \\
\text { женість } \\
\text { хвороби (Р) }\end{array}$ & $\begin{array}{c}\text { Ступінь } \\
\text { прояву } \\
\text { хвороби } \\
(\mathrm{R})\end{array}$ & $\begin{array}{c}\text { Розповсюд- } \\
\text { женість } \\
\text { хвороби (Р) }\end{array}$ \\
\hline Явіс & 29,7 & 40,0 & 3,1 & 10,0 \\
\hline Емеріно & 25,5 & 40,0 & 4,1 & 20,0 \\
\hline Златоглава & 29,2 & 68,0 & 11,4 & 90,0 \\
\hline Скарбниця & 29,2 & 43,0 & 11,5 & 40,0 \\
\hline Ремеслівна & 32,4 & 50,0 & 12,2 & 70,0 \\
\hline Одеська 267 & 41,9 & 72,0 & 12,2 & 90,0 \\
\hline Атава & 40,5 & 55,0 & 17,1 & 42,0 \\
\hline Міхелуа & 43,1 & 100,0 & 22,3 & 73,0 \\
\hline Харус & 39,9 & 70,0 & 25,5 & 30,0 \\
\hline Юнона & 44,2 & 100,0 & 36,6 & 97,0 \\
\hline Трипільська & 43,8 & 100,0 & 42,2 & 100,0 \\
\hline Зорепад & 41,5 & 100,0 & 45,5 & 100,0 \\
\hline Господиня & 36,6 & 90,0 & 52,1 & 60,0 \\
\hline НІР & 1,8 & 4,0 & 1,6 & 3,0 \\
\hline
\end{tabular}

Ступінь прояву септоріозу в 2011 р. був в межах 25,5-44,2 \%. Найнижчий ступінь прояву хвороби був у сорту Емеріно (25,5\%), а найвищий - у сорту Юнона (44,2 \%). Розповсюдженість септоріозу у 2011 р. була також високою. Залежно від сорту вона коливалась від $40 \%$ до $100 \%$. У 2012 р. ступінь прояву захворювання в порвнянні з 2011 р. був значно нижчим: від $3,1 \%$ у сорту Явіс до 52,1 \% у сорту Господиня. Розповсюдженість септоріозу була в межах від 10 \% (сорт Явіс) до ураження всіх рослин (сорти Трипільська та Зорепад). Між ступенем прояву септорізозу на рослинах і рівнем їх поширеності прямої залежності не встановлено. Сорти Явіс та Емеріно незначно уражувались септоріозом і захворювання спостерігалось 
лише на $10 \%$ і $20 \%$ рослин відповідно. Інтенсивність ураження сортів Скарбниця та Златоглава складала 11,5 i $11,4 \%$, але якщо уражених рослин сорту Скарбниця було 90 \%, то в сорту Златоглава - 40 \%. Ступінь ураження септоріозом сортів Трипільська, Зорепад і Господиня був на рівні 42,2 \%, $45,5 \%, 52,1 \%$, розповсюдженість відповідно - $100 \%, 100 \%$ і $60 \%$.

Оцінюючи реакцію сортів на зараження септоріозом, дослідники відзначають, що одні з них більш сприйнятливі, інші більш стійкі. На основі цих даних припускають наявність у патогенів фізіологічних рас [1-3]. У той же час можна припустити, що різниця між сортами за поширеністю захворювання свідчить про гетерогенність сорту.

Періодом найбільш інтенсивного розвитку та високої шкідливості $є$ період колосіння-цвітіння рослин пшениці. В обидва роки досліджень у фазу колосіння зеленими залишались лише листки верхнього ярусу. Кількість уражених листків у 2011 р. у середньому за сортами складала $0,5-1$ листок на стебло, а в 2012 р. від 0,2 до 1 листка на стебло.

Ступінь прояву септоріозу листя в 2011 р залежно від сорту коливався в межах 7,8-10,7\%, розповсюдженість - 20-50\% (табл. 3). Показники інтенсивності та поширеності були найнижчими у сортів Явіс та Емеріно, а найвищими - у сортів Харус, Юнона, Трипільська, Зорепад і Господиня.

Таблиця 3

Ураження верхнього ярусу листків пшениці озимої септоріозом у фазі колосіння залежно від сорту, \%

\begin{tabular}{|l|c|c|c|c|}
\hline \multirow{2}{*}{ Сорт } & \multicolumn{2}{|c|}{$2011 \mathrm{p.}$} & \multicolumn{2}{c|}{$2012 \mathrm{p.}$} \\
\cline { 2 - 5 } & $\begin{array}{c}\text { Ступінь } \\
\text { прояву хво- } \\
\text { роби (R) }\end{array}$ & $\begin{array}{c}\text { Розповсюд- } \\
\text { женість } \\
\text { хвороби (Р) }\end{array}$ & $\begin{array}{c}\text { Ступінь } \\
\text { прояву хво- } \\
\text { роби (R) }\end{array}$ & $\begin{array}{c}\text { Розповсюд- } \\
\text { женість } \\
\text { хвороби (Р) }\end{array}$ \\
\hline Явіс & 7,8 & 20 & - & - \\
\hline Емеріно & 7,8 & 20 & - & - \\
\hline Златоглава & 8,8 & 32 & - & - \\
\hline Скарбниця & 9,8 & 40 & 3,5 & 20 \\
\hline Ремеслівна & 8,6 & 45 & 12,4 & 82 \\
\hline Одеська 267 & 8,9 & 40 & 1,8 & 12 \\
\hline Атава & 9,4 & 35 & 13,2 & 85 \\
\hline Міхелуа & 9,1 & 42 & 4,3 & 74 \\
\hline Харус & 10,6 & 48 & 4,4 & 70 \\
\hline Юнона & 10,3 & 50 & 20,2 & 90 \\
\hline Трипільська & 9,9 & 50 & 24,4 & 100 \\
\hline Зорепад & 10,7 & 50 & 1,8 & 75 \\
\hline Господиня & 10,4 & 50 & 10,2 & 100 \\
\hline НІР & 0,4 & 3,0 & 0,5 & 2,0 \\
\hline
\end{tabular}


У 2012 р. на трьох сортах (Явіс, Емеріно та Златоглава) ознак ураженості захворювання не виявлено. Висока стійкість спостерігалась у сорту Одеська 267: ступінь прояву хвороби $-1,8 \%$, а розповсюдженість - $12 \%$. Ступінь прояву септоріозу на сорті Зорепад також складав $1,8 \%$, але розповсюдженість була високою - 75 \%. Подібна тенденція спостерігалась у сортів Міхелуа та Харус: ступінь прояву хвороби 4,3 і 4,4 \%, розповсюдженість відповідно - 74 і $70 \%$. Найвищий ступінь ураження та розповсюдженість септоріозу виявлено у сорту Трипільська відповідно: 24,4 \% і $100 \%$.

Для септоріозу листя встановлено тісну кореляцію втрат врожаю від ураженості верхівкового листка у фазі молочної стиглості. Фізіологічна причина такої залежності цілком зрозуміла, оскільки верхівковий листок відіграє найбільшу роль у формуванні врожаю. Він у п'ять разів більше другого і третього верхніх листків і постачає зернівку асимілянтами [9].

Кількість уражених листків у фазу молочної стиглості зерна у 2011 p. в середньому за сортами складала 0,5-1 листок на стебло, а в 2012 р. від 0,2 до 1 листка на стебло.

Таблиця 4

Ураження верхнього ярусу листків пшениці озимої септоріозом у фазі

\begin{tabular}{|l|c|c|c|c|}
\hline \multirow{2}{*}{ Сорт } & \multicolumn{2}{|c|}{ молочної стиглості зерна залежно від сорту, \% } \\
\cline { 2 - 6 } & $\begin{array}{c}\text { Ступінь } \\
\text { прояву } \\
\text { хвороби R) }\end{array}$ & $\begin{array}{c}\text { Розповсюд- } \\
\text { женість } \\
\text { хвороби (Р) }\end{array}$ & $\begin{array}{c}\text { Ступінь } \\
\text { прояву } \\
\text { хвороби R) }\end{array}$ & $\begin{array}{c}\text { Розповсюд- } \\
\text { женість } \\
\text { хвороби (Р) }\end{array}$ \\
\hline Явіс & 36,4 & 82 & - & - \\
\hline Емеріно & 36,5 & 80 & - & - \\
\hline Златоглава & 39,0 & 80 & - & - \\
\hline Скарбниця & 40,1 & 85 & 8,5 & 36 \\
\hline Ремеслівна & 39,5 & 83 & 14,2 & 90 \\
\hline Одеська 267 & 39,3 & 88 & 3,8 & 21 \\
\hline Атава & 43,7 & 90 & 14,5 & 100 \\
\hline Міхелуа & 45,0 & 100 & 9,2 & 90 \\
\hline Харус & 44,8 & 100 & 8,4 & 75 \\
\hline Юнона & - & - & 24,5 & 100 \\
\hline Трипільська & - & - & - & - \\
\hline Зорепад & - & - & 3,3 & 100 \\
\hline Господиня & - & - & 15,2 & 100 \\
\hline НІР & 1,7 & 3,0 & 1,5 & 4,0 \\
\hline
\end{tabular}

Ступінь прояву септоріозу листя в 2011 р. залежно від сорту коливався в межах 36,4-44,8 \%, розповсюдженість від $82 \%$ до $100 \%$. У 2012 р. у сортів Явіс, Емеріно та Златоглава на верхніх листках ознак септоріозу не виявлено. У решти сортів ступінь прояву хвороби коливався від 8,5 \% (сорт Скарбниця) 
до 24,5 \% (сорт Юнона). Розповсюдженість септоріозу коливалась від $21 \%$ (сорт Одеська 267) до 100 \% (сорти Атава, Юнона, Зорепад і Господиня).

Стійкість рослин до захворювання - важливий показник, який визначає фітосанітарний стан посівів пшениці озимої. Але це величина змінна, як за роками, так і впродовж вегетації (табл. 5).

Таблиця 5

Стійкість пшениці озимої до септоріозу листя залежно від сорту та фази вегетації за шкалою Саарі та Прескотт, бал

\begin{tabular}{|l|c|c|c|c|c|c|}
\hline \multirow{2}{*}{ Сорт } & \multicolumn{3}{|c|}{$2011 \mathrm{p.}$} & \multicolumn{3}{c|}{$2012 \mathrm{p.}}$. \\
\cline { 2 - 7 } & $\begin{array}{c}\text { вихід у } \\
\text { трубку }\end{array}$ & $\begin{array}{c}\text { колосін- } \\
\text { ня }\end{array}$ & $\begin{array}{c}\text { молочна } \\
\text { стиглість }\end{array}$ & $\begin{array}{c}\text { вихід у } \\
\text { трубку }\end{array}$ & $\begin{array}{c}\text { колосін- } \\
\text { ня }\end{array}$ & $\begin{array}{c}\text { молочна } \\
\text { стиглість }\end{array}$ \\
\hline Явіс & 7 & 3 & 1 & 9 & 7 & 7 \\
\hline Емеріно & 7 & 3 & 1 & 9 & 7 & 7 \\
\hline Златоглава & 7 & 3 & 1 & 9 & 7 & 7 \\
\hline Скарбниця & 7 & 3 & 1 & 9 & 1 & 1 \\
\hline Ремеслівна & 7 & 3 & 1 & 9 & 1 & 1 \\
\hline Одеська 267 & 7 & 3 & 1 & 9 & 1 & 1 \\
\hline Атава & 7 & 3 & 1 & 9 & 1 & 1 \\
\hline Міхелуа & 7 & 3 & 1 & 9 & 1 & 1 \\
\hline Харус & 7 & 3 & 1 & 9 & 1 & 1 \\
\hline Юнона & 7 & 3 & 1 & 9 & 1 & 1 \\
\hline Трипільська & 7 & 3 & 1 & 9 & 1 & 1 \\
\hline Зорепад & 7 & 3 & 1 & 9 & 1 & 1 \\
\hline Господиня & 7 & 3 & 1 & 9 & 1 & 1 \\
\hline
\end{tabular}

У 2011 р у фазі виходу в трубку на всіх сортах спостерігалась слабка інфекція на нижній третині рослини, нижні листки були уражені помірно. У фазу колосіння спостерігалося значне ураження нижніх і середніх листків 3 інфекцією та одиничними проявами на верхівковому листку. В молочній стиглості зерна відмічалось ураження всіх листків, а на сортах Юнона, Трипільська, Зорепад і Господиня провести обліки було неможливо, оскільки листки до цієї фази вегетації відмерли.

У 2012 р. прояв захворювання характеризувався стрімким наростанням у фазу колосіння та молочної стиглості зерна. Так, якщо у фазу виходу в трубку ми спостерігали поодинокі локальні ураження тільки на нижніх листках, то в фазу колосіння і молочної стиглості зерна септоріозом уражені були всі рослини. Проте на сортах Явіс, Емеріно і Златоглава спостерігалось ураження тільки нижніх і середніх листків і поодинокі прояви на верхівковому листку.

Висновки. Ступінь прояву та розповсюдженість септоріозу в посівах пшениці озимої залежать від погодних умов, фази вегетації культури та 
сорту. Найвищою інтенсивність та розповсюдженість захворювання рослин пшениці септоріозом була в фазах колосіння та молочної стиглості зерна. Залежність між ступенем прояву та розповсюдженістю септоріозу листя відрізнялась за сортами.

\section{Список використаних джерел}

1. Ретьман С. В. Септоріоз / С. В. Ретьман, С. І. Коломієць, В. М. Зібцев // Захист рослин. -2002 . - № 5. - С.4-5.

2. Дяк Ю. П. Ареал основных возбудителей септориоза озимой пшеницы на территории Украины / Ю. П. Дяк // Защита растений. - 1990. - Вып. 37. C. 7-9.

3. Сабадин В. Я. Стійкість сортів озимої пшениці до септоріозу та поширення його збудників у Правобережному Лісостепу / В. Я. Сабадин // Зб. наук. праць (спецвипуск) / Інститут землеробства УААН. - К.: ЕКМО, 2004. - C. $82-86$.

4. Дудка Є. Л. Захист озимої пшениці від хвороб / Є. Дудка, П. Ліпс. Дніпропетровськ: Нова ідеологія, 1999. - 20 с.

5. Пахолкова Е. В. Развитие септориоза / Е. В. Пахолкова // Защита растений и карантин.- 1999.- №4.- С. 28-29.

6. Поражаемость сортов озимой пшеницы септориозом (Septoria spp.) и желтой пятнистостью (Pyrenophora tritici-repentis) в условиях Республики Беларусь и Северо-Кавказского региона России / [А. Г. Жуковский, А. Г. Ильюк, С. Ф. Буга, Н. А. Склименок, О. Ю. Кремнева, Г. В. Волкова, Е. С. Гудошникова] // Научный журнал КубГАУ.2012.- № 80 (06).- Електронний режим доступу: [http://ej.kubagro.ru/2012/06/pdf/19.pdf ].

7. Лісовий М. П. Динаміка розвитку септоріозу озимої пшениці та добір стійких ліній / М. П. Лісовий, В. Я. Суська, В. В. Кириленко // Збірник наукових праць. Матеріали наукової конференції “Селекція, насінництво і технологія вирощування цукрових буряків та інших культур бурякової сівозміни", Київ. - 2000. - Вип. 3. - С. 177-182.

8. Лісовий М. П. Імунологічна характеристика сортів озимої пшениці на стійкість щодо септоріозу і створення вихідного матеріалу / М. П. Лісовий, В. Я. Сабадин // Карантин і захист рослин. - 2004. - № 8. - С. 9-10.

9. Защита пшеницы от септориоза / [С. С. Санин, А. А. Санина, А. А. Мотовилин, Е. В. Пахолкова, Л. Г. Корнева, Т. П. Жохова, Г. М. Полякова] // Приложение к журналу “Защита и карантин растений”. - 2012. - № 4. $-82 \mathrm{c}$.

10. Охорона прав на сорти рослин: офіц. бюл. / Каталог сортів і рослин придатних для поширення в Україні у 2011 році (I і II частини) // Мінагропролітики України, Державна служба з охорони прав на сорти рослин, Український інститут експертизи сортів рослин.-К.: ТОВ “Алефа”, 2011. $-510 \mathrm{c}$. 
11. Бабаяни Л. Т. Методы селекции и оценки устойчивости пшеницы и ячменя к болезням в странах - членах СЭВ / Л. Т. Бабаянц, Ф. Мештерхази, А. Вехтер. - Прага, 1988. - 321 с.

12. Методические рекомендации по созданию инфекционных фонов для иммуногенетических исследований пшеницы. / [С. С. Санин, Н. П. Неклеса, А. А. Санина, Е. В. Пахолкова]. - Москва, 2008. - 68 с. 